\title{
Bridging the transactional gap in Open Distance Learning (ODL): The case of the University of South Africa (Unisa)
}

\author{
Blessing Mbatha ${ }^{8}$ and Lynette Naidoo 9 \\ Department of Communication Science, University of South Africa \\ mbathbt@unisa.ac.za,Lnaidoo@unisa.ac.za
}

\begin{abstract}
The aim of this paper is to map and audit the availability and use of e-learning resources by Communication Science students at the University of South Africa (UNISA), in order to ensure that they provide a seamless learning experience to bridge the transactional distance in its Open Distance Learning (ODL) context. The Communication Science students targeted were COMSA executives and Unisa Radio employees. To serve the goal of the paper the following specific objectives were formulated: to establish types of e-learning resources available at Unisa, and to identify the benefits of elearning at Unisa. This study is informed by Michael Moore's Transactional Distance theory. This theory, which focuses on dialogue, transactional distance and telecommunication systems, has been widely applied in many similar studies.

A survey research design was used whereby questionnaires were administered to all COMSA executives and 50\% of Unisa Radio student employees who were chosen using simple random sampling. The data gathered was analysed using thematic categorisation and tabulation and the findings were presented descriptively. The findings indicate that Unisa provides a variety of e-learning resources for its students. In addition, computers and the internet are most useful to students' studies. It should be mentioned that e-learning facilitates and opens avenues for effective teaching. This study focused only on the availability and use of e-learning by Communication Science students at Unisa. Therefore, it will be necessary for a broader study to be undertaken which will focus on academic and ICT staff as well as students chosen across the Unisa community.
\end{abstract}

Keywords: Open Distance Learning; E-learning; Online education; ICTs in teaching and learning, University of South Africa

\section{Introduction}

The purpose of this paper is to map and audit the availability and use of e-learning resources by Communication Science students at Unisa, in order to ensure that they provide a seamless learning experience to bridge the transactional distance in its Open Distance Learning (ODL) context. The Communication Science students targeted were Communication Science Association (COMSA) executives and University of South Africa (UNISA) Radio employees. It should be noted that these groups were targeted because they were in better position to provide valuable data emanating from their active involvement at the Muckleneuk and Sunnyside campuses of UNISA, where the university's central activities originate.

The paper addresses the following research questions: What types of e-learning resources do students have access to? What are useful e-learning resources for students' studies? What are the benefits of using e-learning at Unisa? The respondents were further required to provide recommendations on how to enhance the use of e-learning at Unisa. This paper was based on the assumption that e-learning facilitates and opens avenues for effective teaching because of the potential it has for collapsing the transactional distance between students and the institution; amongst students; and providing easy access of course material regardless of time and location.

In their study, Sonnekus, Louw, and Wilson (2006) narrate that Unisa was founded in 1873 as a university college which offered courses to learners through correspondence. Subsequently, the university migrated through the various developmental stages of distance education and in January 2004 it was constituted as a comprehensive open distance learning university after amalgamation with two similar educational bodies. The 'new' Unisa effectively became the fifth largest mega Open Distance Learning education institution in the world, as it serves approximately 300000 learners. It should be noted that Unisa has students from both rural and urban areas. As a result, this geographical difference impacts on the service delivery of Unisa, which is exacerbated by the mandate given to Higher Education Institutions to enrol 'a large and diverse student body'. Hence, not only is the infrastructure in these areas vastly different, but also the level of exposure to, and availability of modern technology which impacts on the level of technical support that can be given by the learner support system. Unisa's open learning policy promotes open access to courses, flexibility in learning provision, flexibility in methods and criteria of assessing learning process and achievement, and lifelong learning as propagated by the Commonwealth of Learning (Sonnekus, Louw, and Wilson, 2006).

8. Blessing Mbatha is a Lecturer in the Department of Communication Science at the University of South Africa. He is currently finalising his PhD work in the Department of Information Studies at the University of Zululand, South Africa.

9. Lynette Naidoo is a Lecturer in the Department of Communication Science at the University of South Africa, South Africa. 


\section{Literature review}

This study is informed by Michael Moore's transactional distance theory, which includes dialogue, transactional distance and telecommunication systems. This theory has been widely applied in many similar studies. In his theory, Moore (1997) postulates that distance education is not simply a geographic separation of learners and teachers, but a concept describing the universe of teacher-learner relationships that exist when learners and instructors are separated by space and/or by time. This universe of relationships, he notes, can be ordered into a typology that is shaped around the most elementary constructs of the field - namely, the structure of instructional programmes, the interaction between learners and teachers, and the nature and degree of self-directness of the learner. Moore (1997) emphasises the concept of dialogue and asserts that dialogue is developed by teachers and learners in the course of the interactions that occur when one gives instruction and the others respond. The concepts of dialogue and interaction are very similar, and indeed are sometimes used synonymously. However, an important distinction can be made. The term 'dialogue' is used to describe an interaction or series of interactions having positive qualities that other interactions might not have. A dialogue is purposeful, constructive and valued by each party. Each party in a dialogue is a respectful and active participant; each is a contributor, and builds on the contributions of the other party or parties. There can be negative or neutral interactions; the term 'dialogue' is reserved for positive interactions, with value placed on the synergistic nature of the relationship of the parties involved. The direction of the dialogue in an educational relationship is towards the improved understanding of the student.

The transactional distance theory is relevant in this paper because of its reference in bridging the transactional gap in an ODL arena which is the primary objective of e-learning. In order for students to participate in e-learning, they require access to the resources which will enable both the lecturer and student to engage effectively in dialogue.

\section{Distance education}

A point worth mentioning is that higher education as a sector has embraced ICTs, which are seen not only as an impetus of change in traditional concepts of teaching and learning, but also as prime motivations behind the higher education change as the interplay of technological developments and socio-economic change, shape the processes of teaching and learning. The new ICTs have been recognised for the valuable role they can play in developing and improving distance education methods. Many of the advances in this area have been at the level of higher education, but innovative uses have also been introduced in some countries at primary and secondary levels and in the non-formal sector. The Internet obviously provides a wealth of opportunities for the development of distance teaching, with universities and teacher training institutions delivering entire study programmes through this medium. The convergence of telecommunications and video has made possible video teleconferencing which is much in use in higher education institutions in some developed countries. The new technologies make possible new methods and means of delivery for pre-service and inservice teacher education, as well as enabling the development of professional contacts for teachers through the Internet or other electronic networks. In theory, ICTs, through the possibilities they allow for distance learning, could greatly facilitate the provision of teacher education in situations where there are large numbers of untrained teachers, limited inservice training and few training institutions or teacher educators. But it is in these very deprived situations that the basic infrastructure for installing the necessary technologies is likely to be absent (Sloman, 200I and Dunnett, 1994).

\section{Towards open learning}

The possibilities of almost unlimited access to information and global communication offered by ICTs give a new dimension to the concepts of open and lifelong learning. These new media provide a means of overcoming traditional barriers to education available within the limited framework of formal institutions. They can potentially offer individuals the opportunity to control and direct their learning and continually extend, renew and update their knowledge and skills by providing the possibility of easy access to new developments in all fields of knowledge. When put at the service of the wider community, particularly in educationally and socially disadvantaged areas, the new technologies can become catalysts for both individual and collective development and change (Sloman, 200I and Dunnett, 1994).

\section{Methodology}

A survey research design was used whereby questionnaires were administered to all COMSA executives (10; $100 \%)$ and one hundred (100;50\%) of Unisa Radio student employees who were chosen using simple random sampling by taking $50 \%$ of 200 students. The study focused on COMSA executives and Unisa Radio employees because these groups were able to provide valuable data emanating from their active involvement at the Muckleneuk and Sunnyside campuses, where the hub of the university's activities originate. The questionnaire sought information pertaining to personal characteristics of the respondents, student access to e-learning facilities, the use of myUnisa as an e-learning resource and recommendations to improve the use of e-learning at the university. The data collected was analysed through thematic categorisation and tabulation, and the findings were presented descriptively.

Inkanyiso, Jnl Hum \& Soc Sci 2010, 2(I) 


\section{Results and Discussions}

The results are discussed under sections 4.1 to 4.5 .

4.1 Demographic profile of respondents

All the respondents (110; 100\%) were BA: Communication Science students from UNISA. There was a male dominance $(75 \%)$, with most of the respondents under the age of 29 (94.2\%).

\subsection{Types of e-learning resources used by Unisa students}

Figure I below provides responses on the question "Which of the following e-learning resources do you use for your studies? The respondents were provided with a list of options to choose from and asked to respond as was applicable to their situations and also asked to provide those not listed as the figure below illustrates.

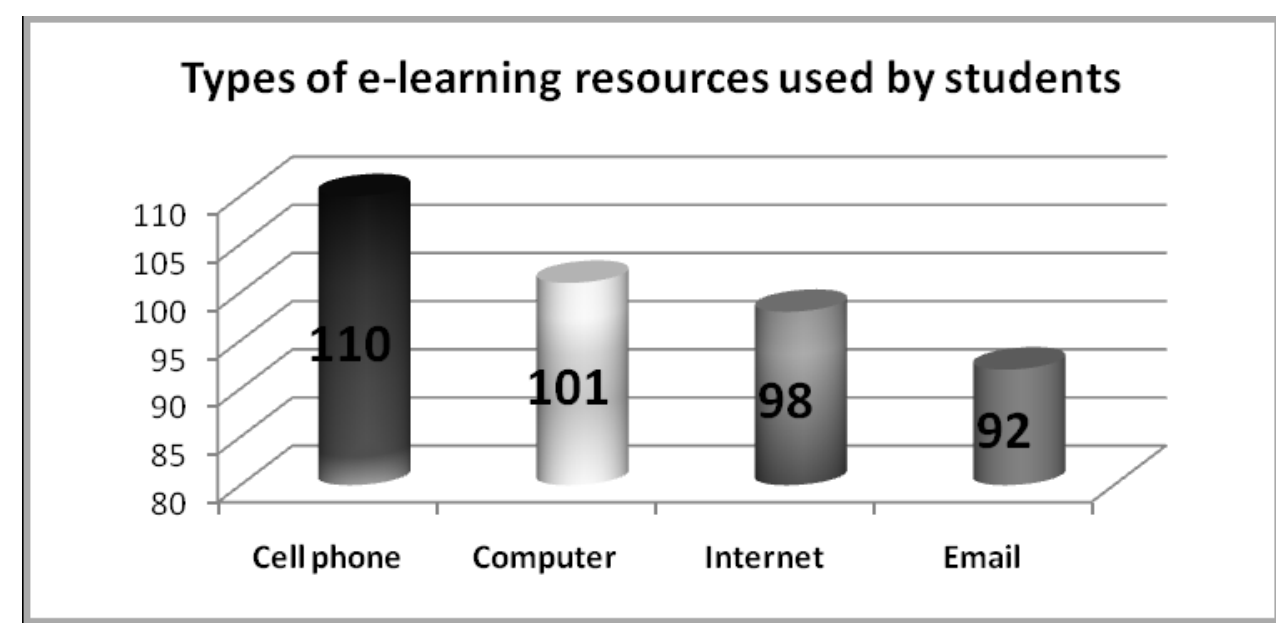

*Figure represents multiple responses

Figure 1 Types of e-learning resources used by Unisa students $(\mathrm{N}=110)$

When asked to comment on the types of e-learning resources they use for their studies, all the respondents (1 10; $100 \%)$ indicated that they use cell phones, while also a significant number $(101 ; 92 \%)$ indicated that they use computers. An examination of data further shows that 98 (89\%) of the students use the Internet for their studies, while $92(87 \%)$ use emails. It is important to note that all students use cell phones for their studies to check their results online, to receive notifications on their assignments they have submitted, etc. This could be attributed to the fact that all students have cell phones. Unisa sends information to its students to their cell phones pertaining to the submission of assignments, results, examination dates, etc. In distance learning, the students control the learning environment because they can decide when and where to learn and how long to take over a course. Information technology can facilitate the whole process.

In addition, the student can send assignments and questions to the lecturer using e-mail and the lecturer can also respond using e-mail. Furthermore, an institution may put the courses on a web site that is password protected. A student either reads the coursework directly on the Internet or downloads it from the Internet. This has obvious cost and administrative savings for the institution. It also means that the institution can enrol students from all over the world. Moreover, registration and payment of fees can also be done on-line (Pawar, 2008, and Pakhare, 2007). This confirms what the theory informing this study emphasises that in order for e-learning to be effective each party in a dialogue is a respectful and active participant; each is a contributor, and builds on the contributions of the other party or parties (Moore, 1997). Thus, it is important for students to have access to e-learning so that they can communicate with their lecturers as the results above indicate.

\subsection{Useful e-learning resources on students' studies}

The study sought to establish e-learning resources that are more useful in students' studies. In this connection, respondents were therefore provided with a list of possible e-learning resources to choose from as was applicable to their situations. Figure 2 below summarises responses 


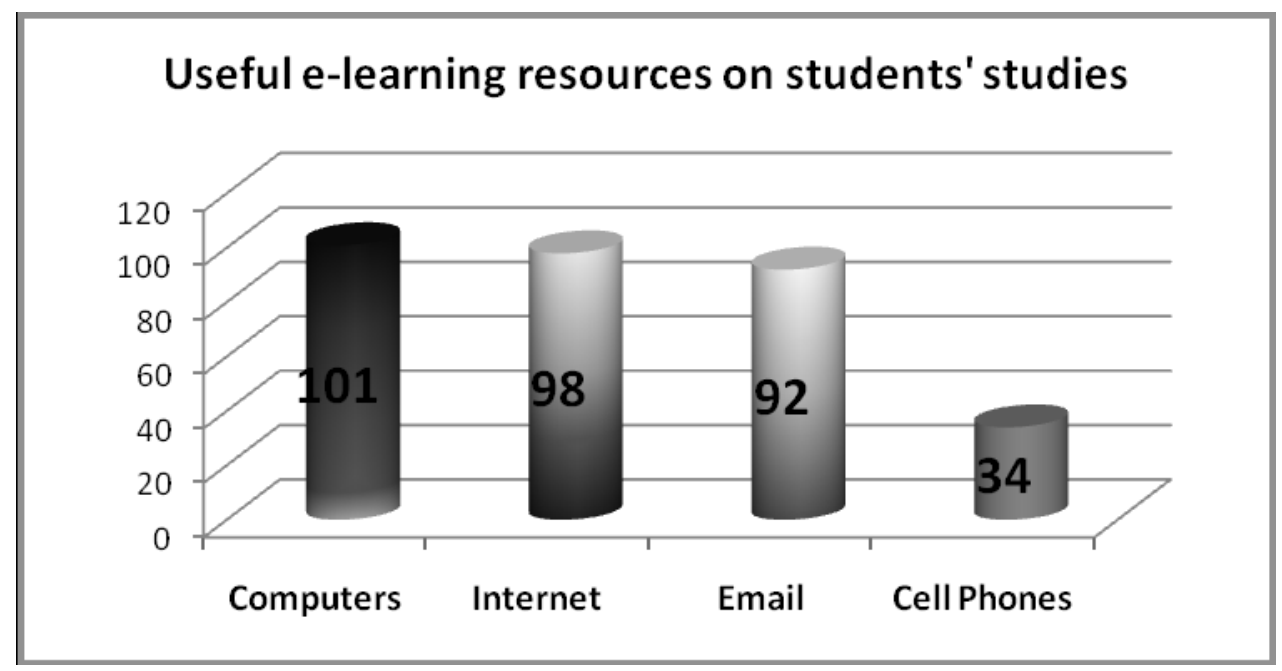

*Figure represents multiple responses

.Figure 2 Useful e-learning resources on students' studies $(\mathrm{N}=110)$

When asked to comment on useful e-learning resources, the majority of respondents $(101 ; 92 \%)$ indicated that computers are useful e-learning resource. Of the respondents, $98(89 \%)$ felt that the Internet is useful, while $92(84 \%)$ said it is email. Those who said cell phones are useful were the minority (34; $31 \%)$. Kumar (2009) concurs with these results by observing that education system is revolutionised with the help of the internet. Consequently, new learners do not have to solely depend on teachers. Students can search and access the required study material from the internet with help of search engine like Google, Yahoo to name a few. For example, at the University of South Africa it is where the internet is playing a major role in teaching and learning. It should be noted that with the help of the Internet Unisa has enrolled students from all over the world. It is also true that an electronic learning tool popularly known as myUnisa cannot function without the Internet.

In item 4.I, figure I, students were required to indicate e-learning resources they use for their studies. The study findings show that all the respondents $(110 ; 100 \%)$ use cell phones for their studies. However, it is worth mentioning that although all of them use cell phone, but it does not necessarily mean that cell phones are effective. This is based on the findings where the minority $(34,31 \%)$ indicated that cell phones are useful in their studies, hence in item 4.1 all the respondents indicated that they use cell phones in their studies.

\subsection{Benefits of e-learning}

One of the objectives of the paper was to identify the benefits of e-learning on Unisa students. Respondents were therefore required to deliberate on the benefits offered by e-learning resources at Unisa. Respondents generally noted that:

- I have benefited immensely because interaction with fellow students exposed me to relevant information pertaining to the content of the modules through myUnisa and emails.

- E-learning offers a number of advantages because it enables me to access large volumes of information anytime.

- I can now use the Internet and electronic mails to interact with people outside my studies.

- I have definitely benefited because I am able to send assignments to my lecturers speedily.

- It has improved the way we do our work and the way we communicate, thus, I can communicate with my peers abroad.

- I interact regularly with fellow students and lecturers and the response rate is very fast.

- The advantage of using e-learning resources such as myUnisa and emails is that it is very fast. This is especially useful when students are submitting their assignments. When students submit their assignments through the post it takes an extra-ordinary long time to process and to receive an SMS confirming that the assignment has been received.

- You can access the latest information thereby keeping abreast of global trends.

- I can access my marks and other relevant information pertinent to my studies using myUnisa.

- Accessing computers and the Internet from schools is much better than using these resources at the Internet café. 
It is worth noting that there are many significant advantages for students who learn online. In his study James (2007) outlines advantages of e-learning which include convenience and portability; cost and selection; flexibility; retention; greater collaboration and global opportunities. Sharing similar sentiments the White Paper (Republic of South Africa, 2004) indicates that the use of technology or e-learning encourages collaborative work amongst learners, as well as learner-centred and active learning.

One of the most important advantages of e-learning is the interaction and engagement that students are exposed to. Thus, the success of one student encourages others. This is consistent with the principle that learning is also a social experience and that all the elements that comprise the learning experience are important and will also contribute in motivating students to engage with the learning material. These views are shared by Pawar (2008) and Pakhare (2007) who observe that the Internet contains enormous quantities of information. Some of this is excellent, some very poor and much incorrect. It should be noted that to access information on the Internet, a student makes use of a search engine such as Google. Feeding in a number of key words can result in a list of many thousands of sites being displayed. Each of these is represented by a hyperlink. This is a link to another site. When you click on a hyperlink, you are immediately taken to the site. In strengthening the aforementioned views James (2007) and Kruse (2004) state that instructional design for e-Learning has been perfected and refined over many years using established teaching principles, with many benefits to students. As a result, colleges, universities, businesses, and organisations worldwide now offer their students fully accredited online degree, vocational, and continuing education programs in abundance.

4.5 Recommendations to improve the use of e-learning resources at Unisa

The respondents were required to indicate contextual conditions that need to be adapted in order to enhance the use of e-learning resources at Unisa. The respondents generally felt that:

- Lecturers should see students at least twice a week in order to increase the interaction to discuss content and guide and encourage students on how to use e-learning effectively.

- All computer labs at Unisa should have internet connection because some of the students only use myUnisa in order to send their work and access my Unisa.

- Unisa must promote e-learning resources and make sure that students have internet access in order to partake effectively with these useful tools and services.

- Unisa should build a technology centre with e-learning resources in each region where students have access in order to progress smoothly.

- Unisa should provide faster computers and increase internet bandwidth.

- Build more computer labs with faster computers and the internet so that we do not wait for long hours for space to open.

\section{Conclusion}

The paper set out to map and audit the availability and use of e-learning resources by Communication Science students at Unisa, in order to ensure that they provide a seamless learning experience to bridge the transactional distance in its ODL context. This study is informed by Michael Moore's Transactional Distance theory, which includes dialogue, transactional distance and telecommunication systems. The findings indicate that e-learning resources such as the internet and computers are very useful on students' studies. Education system is revolutionised with the help of the internet. The emergence of e-learning has created a new platform for the delivery of training and the impact of this technology will create opportunities that will enhance and transform the learning experience for both student and teacher. The application of e-learning has grown considerably in recent years and has triggered a great deal of interest in this age of rapid technological progress, transforming "the very nature" of higher education. It should be mentioned that e-learning facilitates and opens avenues for effective teaching. This is because of the potential it has for collapsing the transactional distance between students and the institution; interaction between students and between students and lecturers and above all students can view their course material regardless of time and location. We have noted the limitations of this study in that it focused only on the availability and use of e-learning by Communication Science students at Unisa. A further study to be undertaken should focus on academic and ICT staff as well as students chosen across the Unisa community. The results of this study could have been affected by the views and dominant complaint nature of students.

\section{References}

Dunnett, C. 1994. Telecomedia! - telecommunications and media in distance education. Educational media international (London), vol. 31, no. 3, p. 197-20I.

James, G. 2007. Advantages and Disadvantages of Online Learning. [Online] http://www.comminit.com/en/node/2 10058/36 Accessed 12/04/09. 
Kruse, K. 2004. The Benefits and Drawbacks of e-Learning. [Online] http://www.e-learningguru.com/articles/ezine/gurul_I0.htm Accessed: 10/04/09.

Kumar, R. 2009. Advantages of the Internet [Online] http://www.helium.com/items/9278/8-the-advantages-of-theinternet?page $=2$ Accessed: $12 / 08 / 09$.

Moore, M.G. 1997. Theory of transactional distance. [Online] http://www.aged.tamu.edu/research/readings/Distance/ 1997MooreTransDistance.pdf Accessed I2/03/09.

Pakhare, J. 2007. Advantages and Disadvantages of the Internet [Online] http://www.buzzle.com/articles/advantagesdisadvantages-internet.html Accessed:01/09/09.

Pawar, D. 2008. Uses of the Internet. Retrieved September 29, 2009, from http://ezinearticles.com/?Uses-of-theInternet\&id=1034725 Accessed 10/08/09

Republic of South Africa. 2004. White Paper on e-Education.

Sloman, M. 200I. The e-learning revolution: from proposition to action. [Online] http://www.ics.heacademy.ac.uk/Events/ HEADublin2006 V2/Kamal.htm Accessed: 22/08/ 2009.

Sonnekus, P., Louw, W. \& Wilson, H. 2006. Emergent learner support at Unisa: An informal report. In Progressio, 28 (I) 